\title{
Model Kewirausahaan Sosial pada Komunitas Muslim Rumah Harapan Karangpatihan Bangkit
}

\author{
Nur Izza Safira, Charolin Indah Roseta \\ STID Al-Hadid Surabaya \\ Email :charolin@stidalhadid.ac.id
}

\begin{abstract}
Abstrak:
Pengembangan masyarakat Islam merupakan sebuah proses peningkatan kualitas hidup manusia dalam masyarakat untuk dapat mengembangkan diri dalam rangka meningkatkan kesejahteraan mereka sendiri. Dalam hal ini Islam mengajarkan prinsip keadilan sosial kepada setiap insan termasuk kepada kaum tunagrahita yang oleh karena keterbatasannya memerlukan suatu program kesejahteraan sosial yang dapat mengangkat derajat hidupnya salah satunya dengan program Kewirausahaan sosial.Tulisan ini mendeskripsikan tentang model kewirausahaan sosial RHKB yang sukses diterapkan pada kaum tunagrahita dengan indikator kemandirian ekonomi dan peningkatan status sosial di masyarakat. Studi terdahulu tentang tema pemberdayaan RKHB telah banyak dilakukan, namun belum ada yang membahas model kewirausahaan sosial yang sukses diterapkan dengan konteks khusus seperti kaum disabilitas intelektual muslim di Karangpatihan. Metode yang digunakan dalam kajian ini adalah kualitatif dengan jenis kajian pustaka. Temuan yang dihasilkan adalah Keberhasilan RHKB tidak terlepas dari model kewirausahaan yang dipilihnya yaitu cenderung sama seperti hybrid social entreprise namun tetap memiliki karakteristiknya sendiri terutama pada indikator revenue stream dan goal organization karena adanya penyesuaian dengan kondisi tunagrahita itu sendiri.
\end{abstract}

Kata Kunci:Kewirausahaan sosial, RHKB, Tunagrahita

\begin{abstract}
:
The development of the Islamic community is a process of improving the quality of human life in society so that it can develop and improve its own well-being. In that case, Islam teaches the principle of social justice to all human beings, including people with mental disabilities. Due to its limitations, they need a social assistance program that can improve their standard of living. The social entrepreneurship program is an example. The journal describes how social entrepreneurship in Rumah Harapan Karangpatihan Bangkit (RHKB) has been successfully implemented for people with mental disabilities with indicators of economic independence and increased social status in society. Previous studies about empowerment themes like in RHKB have done a lot, but there has not discussed the social entrepreneurship model that has been successfully applied for a special context such as Muslim intellectual disabilities in Karangpatihan. The methodology of this study is qualitative descriptive with the kind of literature review. The result is how RHKB successfully implemented the entrepreneurship model that chosen, hybrid social enterprise but still has its characteristics on revenue stream and goal organization indicators according to the mentally disabled conditions.
\end{abstract}

Keywords: social entrepreneurship, RKHB, mentally disabled

\section{Pendahuluan}


Pengembangan masyarakat Islam merupakan sebuah proses peningkatan kualitas hidup manusia dalam masyarakat untuk dapat mengembangkan diri dengan potensi skill, wawasan dan sumber daya yang ada dalam rangka meningkatkan kesejahteraan mereka sendiri sesuai dengan tuntunan syariat Islam.1Dalam hal ini Islam mengajarkan prinsip keadilan sosial kepada setiap insan termasuk kepada kaum tunagrahita yang oleh karena keterbatasannya memerlukan suatu program kesejahteraan sosial yang dapat mengangkat derajat hidupnya. Pendidikan, pelatihan dan pendampingan termasuk bagian dari program pensejahteraan bagi para Tunagrahita yang dilakukan untuk memaksimalkan potensi mereka dalam segi kemanusiaan, potensi fisik, keterampilan, inteligensi, moral, dan sebagainya, sehingga dapat menjalankan fungsi hidup sebagai hamba Allah dan khalifah-Nya. ${ }^{2}$ Adapun secara jumlah tunagrahita di Indonesia mencapai $13,68 \%$ atau lebih tepatnya sekitar 290,837 jiwa. ${ }^{3}$ Persebaran jumlah tunagrahita tertinggi di Indonesia berada pada kabupaten Ponorogo ${ }^{4}$ dimana salah satu desa bernama Karangpatihan dikenal sebagai Kampung Idiot atau Kampung Tunagrahita.Sebab, desa ini memiliki penduduk penderita tunagrahita terbanyak. ${ }^{5}$

Tunagrahita merupakan istilah untuk orang-orang yang memiliki kemampuan intelektual dan kognisi dibawah rata-rata dibanding orang-orang seusianya. ${ }^{6}$ Tunagrahita di desa Karangpatihan memiliki tiga tingkatan, tingkatan ringan yang ditandai dengan masih bisa untuk diajak berbicara namun cara berfikirnya lemah seperti anak-anak, lalu tingkatan sedang yang ditandai dengan cara berfikirnya lemah disertai bisu dan tuli, dan yang terakhir tingkatan berat yang ditandai dengan kemampuan yang hanya bisa tersenyum dan memberikan simbol-simbol untuk komunikasi. ${ }^{7}$ Dari keterbatasan kemampuan ini membuat mereka susah memiliki pekerjaan atau malah menjadikan mereka seorang pengangguran sehingga tidak ada penghasilan yang dimiliki untuk menyongsong kehidupan mereka. Secara umum kondisi dari desa Karangpatihan itu sendiri yang merupakan desa tertinggal dengan hampir seluruh penduduknya beragama Islam ${ }^{8}$.

Secara geografis desa ini memiliki lahan yang tandus, dikelilingi oleh perbukitan kapur, sulit air dan tanah disana tidak mengandung yodium. Dalam kondisi tersebut, justru mayoritas masyarakat desa Karangpatihan berprofesi sebagai petani dengan komoditas yang ditanam dan dikonsumsi adalah singkong yang minim gizi. ${ }^{9} \mathrm{Hal}$ ini,

1 Kamaluddin, "Dakwah dan Pengembangan Masyarakat Islam (Konsep Dasar dan Arah Pengembangan", Jurnal Hikmah, Vol. 08, No. 02.(2014),43.

${ }^{2}$ Aziza Meria, "Model Pembelajaran Agama Islam bagi Anak Tunagrahita di SDLB YPPLB Padang Sumatera Barat”, Jurnal Peradaban Islam, Vol. 01, No. 02.(2015), 355.

3 Kementrian Sosial Republik Indonesia, Kementrian Sosial dalam Angka Pembangunan Kesejahteraan Sosial, (Jakarta:Badan Pendidikan dan Kajian Kesejahteraan Sosial Pusat Data dan Informasi Kesejahteraan Sosial,2012), 54.

${ }^{4}$ Aries Susanto, "Daerah Tertinggal Ponorogo : Inilah Cerita di Balik Desa Keterbelakangan Mental Terbanyak di Indonesia" dalam www.solopos.com/7-Januari-2015/diakses20-januari-2021.

5 NET.Documentary, "Kisah Eko Mulyadi Pemerhati Tuna Grahita di Ponorogo", dalam www.youtube.com/18-Oktober-2015/diakses20-Januari-2021.

6 Denisa Libela Haimi, "Hubungan Down Syndrome dengan Tunagrahita", dalam www.alodokter.com/31-Januari-2019/diakses 21-Januari-2021.

7The Nation Metro TV, “Bukan Desa Idiot (2/3)”, dalam www.youtube.com/9-Oktober-2019 21januari-2021.

${ }^{8}$ Amila, Pemberdayaan Ekonomi Masyarakat TunaGrahita melalui Kelompok Swadaya Masyarakat Rumah Harapan Karangpatihan Bangkit (Studi Kasus di Desa Karangpatihan Kecamatan Balong Kabupaten Pono/diaksesrogo).Tesis Universitas Islam Negeri Maulana Malik Ibrahim Malang, 2017. 107.

9 NET.Documentary, "Kisah Eko Mulyadi Pemerhati Tuna Grahita di Ponorogo", dalam www.youtube.com/18-Oktober-2015/diakses 20-Januari-2021. 
menjadi penyebab desa Karangpatihan bertahun-tahun tidak terlepas dari lingkaran kelahiran tunagrahita. Masyarakat tunagrahita sendiri tidak ada yang memiliki lahan pertanian maka sebagian dari mereka adalah pengangguran dan sebagian lain adalah pekerja serabutan sebagai buruh tani, yang tidak selalu ada pekerjaan juga untuk mereka. Sehingga, penghasilan yang mereka peroleh tidak cukup untuk memenuhi kebutuhan hidup mereka. ${ }^{10}$ Makanan yang mereka konsumsi seadanya, yang terpenting adalah kenyang, tidak memperhatikan gizi, seperti tiwul dan aking. ${ }^{11}$ Akhirnya, untuk menutupi kebutuhannya, masyarakat tunagrahita menjadi seseorang yang menggantungkan hidup pada bantuan orang lain ataupun BLT dari pemerintah yang sifatnya hanya konsumtif. ${ }^{12}$

Sejauh ini Pemerintah Indonesia telah melakukan upaya untuk meningkatkan kesejahteraan tunagrahita desa Karangpatihan namun dalam penerapannya masih belum optimal dan perlu banyak perbaikan. ${ }^{13}$ Sehingga sangat diperlukan peranan dari masyarakat untuk memperbaiki kondisi tunagrahita supaya bisa memiliki kemampuan untuk menyelesaikan masalah kesejahteraan mereka sendiri.Salah satu alternatif strategi dalam melakukan peningkatan kesejahteraan adalah dengan melaksanakan program Kewirausahaan sosial ${ }^{14}$. Kewirausahaan sosial adalah kegiatan kewirausahaan yang tidak hanya berorientasi pada profit melainkan juga pada tujuan sosial/ pemecahan masalah sosial yang ada dimasyarakat ${ }^{15}$. Kewirausahaan sosial juga terbukti mampu berperan mendorong perbaikan perekonomian masyarakat secara mandiri sebab terciptanya lapangan pekerjaan yang dapat menciptakan pendapatan ${ }^{16}$.Dengan terbukanya lapangan kerja tersebut masyarakat yang diberdayakan bisa dilibatkan dalam kegiatan kewirausahaan sosial tersebut.Terdapat asumsi umum bahwa kesuksesan dalam melaksanakan kewirausahaan sosial tidak lepas dari kesesuaian dengan model kewirausahaan Sosialnya.Hal ini dikarenakan setiap model kewirausahaan memiliki karakteristik operasional masing-masing yang menyesuaikan kondisi/situasi yang dihadapi oleh lembaga/komunitas sosial.Sehingga, model kewirausahaan sosial memiliki kedudukan yang sangat penting dalam kewirausahaan sosial. ${ }^{17}$

Bornstein dalam Suyanto berargumen bahwa kesuksesan penerapan model kewirausahaan sosial mensyarakatkan adanya sumberdaya keuangan ${ }^{18}$ dan sumberdaya manusia yang berkualitas. ${ }^{19}$ Namun cukup menarik untuk dikaji bahwa terdapat fenomena kesuksesan kewirausahaan sosial yang diterapkan oleh RHKB dalam mengentaskan kemiskinan masyarakat justru berhadapan dengan kondisi minimnya sumberdaya

${ }^{10}$ Ibid.

11 The Nation Metro TV, "Bukan Desa Idiot (1/3)", dalam www.youtube.com/9-Oktober2019/diakses 20-Januari-2021.

${ }^{12}$ Amila, Pemberdayaan Ekonomi,2.

13 Mahendra Ramadhianto, Upaya Peningkatan Kesejahteraan Sosial bagi Penyandang Cacat (Studi Implementasi Pasal 7 Undang-Undang Republik Indonesia Nomor 11 Tahun 2009 tentang Kesejahteraan Sosial di Desa Karangpatihan Kecamatan Balong Kabupaten Ponorogo). Skripsi Universitas Brawijaya Malang, 2013. 10.

14 Muhammad Wildan Aziz, "Kewirausahaan Sosial sebagai Alternatif Pemberdayaan Masyarakat", Jurnal Institut Pertanian Bogor. Vol. 06, No. 05.(2018), 15.

${ }^{15}$ Nur Firdaus, "Pengentasan Kemiskinan melalui Pendekatan Kewirausahaan Sosial", Jurnal Ekonomi dan Pembangunan Lembaga Ilmu Pengetahuan Indonesi. Vol. 22, No. 01.(2014), 59.

16 Nur Firdaus, Pengentasan Kemiskinan, 61.

17 Dewi Meisari Haryanti, dkk.Berani Jadi Wirausaha Sosial? (Depok:PT Bank DBS Indonesia,2015), 212.

18Mawasti, Wahanani, and Tri Djoyo Budiono."Memberdayaan Masyarakat Islam Melalui Bank Sampah:Strategi Komunikasi Stakeholder Bank Sampak Songolikoer". Inteleksia-Jurnal Pengembangan Ilmu Dakwah.Vol. 01, No.02.(2020), 281-304.

${ }^{19}$ Suyanto, dkk.Kewirausahaan Sosial dan Tranformasi Lingkungan di Jawa Timur, Laporan Kajian Kompetitif, 2015.06. 
keuangan daerah dan minimnya kualitas SDM seperti penyandang tunagrahita.Dalam hal ini RHKB merupakan organisasi yang dibangun oleh swadaya masyarakat Karangpatihan untuk menciptakan kemandirian ekonomi masyarakat tunagrahita di desanya sehingga mereka dapat hidup mandiri tanpa bergantung lagi pada bantuan konsumtif dari orang lain dengan cara memberdayakan mereka melalui kewirausahaan sosial. ${ }^{20}$ Sejak didirikan pada tahun 2013, program-program RHKB banyak difokuskan pada pemberdayaan ekonomi yang ditunjukkan dengan pemberian penguatan modal usaha (alat dan bahan baku usaha), pelatihan, penguatan pendampingan, penguatan pemasaran kepada masyarakat tunagrahita ${ }^{21}$

Eko Mulyadi adalah Kepala Desa Karangpatihan yang berperan sebagai penggagas Rumah Harapan memiliki inisiatif memberdayakan Tunagrahita menjadi SDM produksi di KSM RHKB dengan melakukan pelatihan dan pendampingan agar mereka bisa memiliki pendapatan yang bisa menolong masalah perekonomian mereka sendiri. Dibawah kepemimpinannya beserta tim pengurus RHKB mampu menorehkan kesuksesan dalam pemberdayaan lewat model kewirausahaan social yang diterapkannya selama kurun waktu tujuh tahun terakhir dengan indicator peningkatan kesejahteraan Tunagrahita hingga $73,3 \%$ dari kondisi sebelumnya. ${ }^{22}$ Dalam hal ini masyarakat Tunagrahita yang diberdayakan dalam kewirausahaan sosial Rumah Harapan bisa memiliki pekerjaan dan pengahasilan mandiri sehingga terjadi peningkatan kemampuan masyarakat untuk memenuhi kebutuhan hidupnya secara layak. ${ }^{23}$ Selain itu saat ini sudah tidak ditemukan kelahiran tunagrahita di desa Karangpatihan dan bahkan terjadi penurunan penderita tunagrahita di wilayah ini.Hal tersebut disinyalir karena adanya peningkatan gizi bagi anak keturunan mereka seiring dengan peningkatan pendapatan di RHKB.24Disamping peningkatan ekonomi juga terdapat implikasi lanjutan dari peran Eko Mulyadi lewat kewirausahaan sosial di RHKB yakni peningkatan kualitas hidup para Tunagrahita dalam bidang spiritualitas Islam, jiwa dan keturunan yang sehat, serta pemeliharaan akal sesuai dengan tujuan syariat Islam al-dharuriyyat al-khams. ${ }^{25}$

Kesuksesan kewirausahaan sosial yang dilakukan oleh RHKB tidak lepas dari model kewirausahaan sosial yang diterapkannya. Sebelumnya, para tunagrahita adalah pengangguran dan mengandalkan hidup dari uluran orang lain. Terdapat stigma yang melekat pada masyarakat umum yakni tunagrahita adalah orang yang dianggap tidak bisa apa-apa sehingga upaya untuk menolong mereka hanya bisa dilakukan dengan bantuan yang bersifat konsumtif.Namun, penggagas Rumah Harapan meyakini bahwa para tunagrahita bisa diberdayakan sehingga bisa hidup mandiri dan layak seperti orang normal.Dari keyakinan itu, para tunagrahita dijadikan sebagai bagian dari SDM pada RHKB ini dan produk kewirausahaannya disesuaikan dengan kondisi tingkat keparahan masyarakat tunagrahita ditunjang dengan pelatihan kemampuan skill sehingga produksi tetap bisa berjalan.Dari adanya program RHKB ini, sekarang para tunagrahita memiliki pekerjaan tetap dan penghasilan secara mandiri.

${ }^{20}$ Sari Nurfiani, Kewirausahaan Sosial dan Taraf Hidup Masyarakat Tunagrahita (Kajian di "Kampung Idiot" Desa Karangpatihan, Kabupaten Ponorogo, Jawa Timur.Skripsi Institut Pertanian Bogor, 2017.

${ }^{21}$ Amila, Pemberdayaan Ekonomi, 17.

${ }^{22}$ Sari Nurfiani, Kewirausahaan Sosial, 44-47.

${ }^{23}$ Amila, Pemberdayaan Ekonomi Masyarakat TunaGrahita melalui Kelompok Swadaya Masyarakat Rumah Harapan Karangpatihan Bangkit (Studi Kasus di Desa Karangpatihan Kecamatan Balong Kabupaten Ponorogo).Tesis Universitas Islam Negeri Maulana Malik Ibrahim Malang, 2017.111.

${ }^{24}$ The Nation Metro TV, "Bukan Desa Idiot (2/3)", dalam www.youtube.com/9-Oktober2019/diakses 21-januari-2021.

${ }^{25}$ Maulida Agustina Hidayatul Wahidah, Peranan Tokoh Social Entrepreneur dalam Pemberdayaan Masyarakat Perspektif Maqa, Studi Kasus atas Peran Eko Mulyadi di Desa Karangpatihan Balong Ponorogo.Tesis Universitas Islam Negeri Sunan Ampel Surabaya, 2020. 112-124. 
Secara umum kajian tentang model kewirusahaan sosial di Indonesia masih belum banyak dikembangkan. Adapun Drucker dalam Suyanto berargumen bahwa proses kewirausahaan di negara berkembang, bersifat "imitasi kreatif", merujuk pada cara pengadopsian proses produksi dari berbagai belahan dunia. Dengan demikian, kajian model kewirausahaan sosial untuk Indonesia menjadi sangat penting, untuk memperlihatkan bahwa terdapat model adaptasi yang cocok untuk kondisi Indonesia, yang tidak hanya sekedar mengadopsi langsung dari model yang ada di negara maju. Senada dengan hal ini menurut terbatasnya literatur empiris berkaitan dengan kewirausahan sosial menjadikan kajian aplikatif sangat diperlukan. ${ }^{26}$ Dengan alasan tersebut, kajian ini mengkaji bentuk model kewirausahaan sosial di Ponorogo Jawa Timur khususnya yang dalam hal ini telah terbukti berhasil diterapkan pada konteks masyarakat penyandang tunagrahita.

Oleh karenanya focus kajian ini adalah bagaimana deskripsi model kewirausahaan sosial yang dilakukan oleh Kelompok Rumah Harapan Karangpatihan Bangkit (RHKB) pada masyarakat tunagrahita desa Karangpatihan Ponorogo yang bertujuan untuk mengidentifikasi dan mendeskripsikan model kewirausahaan sosial yang dilakukan oleh RHKB pada masyarakat tunagrahita desa Karangpatihan Ponorogo. Kajian mengenai kiprah pemberdayaan masyarakat dan kewirausahaan sosial RHKB sudah banyak dilakukan baik dalam jurnal dan buku-buku ilmiah, namun belum ada yang mengkaji tentang model kewirausahaan sosialnya. Beberapa karya ilmiah banyak mengangkat tema RHKB adalah Okky Sepprian ${ }^{27}$, Amalia ${ }^{28}$ dan Dian Suluh ${ }^{29}$ yang berfokus pada mengkaji peranan RHKB dari aspek model dan bentuk program pemberdayaannya terhadap masyarakat Tunagrahita di Desa Karangpatihan. Sedangkan focus kajian ini dispesifikkan pada bentuk model kewirausahaan sosial berikut karakteristiknya. Adapun karya ilmiah lain yang mengangkat tema kewirausahaan RHKB adalah Sari Nurfiani dengan kajian berjudul "Kewirausahaan Sosial dan Taraf Hidup Masyarakat Tunagrahita (Kajian di 'Kampung Idiot' Desa Karangpatihan, Kabupaten Ponorogo, Jawa Timur) ${ }^{30}$ dengan temuan bahwa Rumah Harapan mampu meningkatkan kesejahteraan ekonomi dan sosial warga tunagrahita dengan usaha keset kain perca (73,3\%) meskipun indeks taraf hidup mereka paling rendah di masyarakat desa Karangpatihan. Namun selain perbedaan dalam metode kuantitatif yang digunakan, dalam kajian ini lebih difokuskan pada mengidentifikasi model kewirausahaan sosial apa yang dipilih oleh RHKB dan bukan pada korelasi antara kapasitas kewirausahaan sosial yang dilakukan dengan taraf hidup tunagrahita.

\section{Metode Penelitian}

Metode yang digunakan dalam kajian ini adalah kualitatif dengan jenis kajian pustaka.Dalam tulisan ini tidak bertujuan untuk mengeneralisasikan melainkan memperoleh pemaknaan yang mendalam dari objek yang diteliti yang bersifat dinamis.Jika dikontekskan dalam penelitian ini maka penelitian ini hendak mencari pemaknaan yang mendalam mengenai model kewirausahaan yang dilakukan oleh KSM RHKB pada tunagrahita di desa Karangpatihan tahun 2013-2020. Data yang terkumpul bersifat deskriptif sebab data-data berupa gambaran lengkap yang berkaitan dengan

\footnotetext{
${ }^{26}$ Suyanto, Kewirausahaan Sosial, hal. 5

${ }^{27}$ Okky Sepprian, "Pemberdayaan Masyarakat melalui Rumah Harapan dalam Memberikan Life Skill Kerajinan Tangan Warga Tunagrahita Desa Karangpatihan Kecamatan Balong Kabupaten Ponorogo", Jurnal Universitas Negeri Surabaya.Vol. 07, No.02.(2018), 11.

${ }^{28}$ Ibid.

29 Dian Suluh Kusuma Dewi, "Model Pemberdayaan Masyarakat Tunagrahita di Kampung Idiot Kabupaten Ponorogo", Jurnal Ilmu Pemerintahan. Vol. 06, No.01.(2016), 13.

30 Ibid
} 
model kewirausahaan sosial RHKB yang berbentuk kata-kata atau gambar sehingga tidak menekankan pada angka atau tidak perlu dikuantifikasikan. ${ }^{31}$ Data bisa dianalisis sejak awal pengumpulan data kemudian direduksi, dikelompokkan hingga memberikan interpretasi, bukan dianalisis dengan menggunakan perhitungan statistik serta disajikan dalam bentuk deskripsi detail bukan berupa angka. ${ }^{32}$

Dalam kajian ini sumber-sumber data tersebut diperoleh dari dokumen-dokumen tertulis dari tesis, skripsi, jurnal, surat kabar, foto, video, dan lain-lain yang memiliki tema model kewirausahaan sosial yang dilakukan RHKB. Adapun data yang digunakan dalam kajian ini adalah sumber tesis dari tentang pemberdayaan ekonomi tunagrahita ${ }^{33}$, skripsi dan jurnal tentang model pemberdayaan dan bentuk kewirausahaan social yang dilakukan. ${ }^{34}$ Teknik analisis data yang digunakan pada penelitian ini adalah teknik yang dikemukakan oleh Miles dan Huberman. ${ }^{35}$ Sebab pada penelitian ini sumber datanya sekunder dari dokumen maka untuk memastikan bahwa data yang didapat valid diperlukan metode Triangulasi sumber adalah pengecekan kembali data yang telah diperoleh dengan berbagai sumber lain sehingga didapatkan data yang valid, konsisten dan pasti, ${ }^{36}$ merta meningkatkan ketekunan adalah peneliti melakukan pengamatan yang lebih jelih terhadap penelitiannya ${ }^{37}$.

\section{Pembahasan dan Hasil Penelitian Pengertian dan Model Kewirausahaan Sosial}

Menurut Cukier dalam Sofia, Social entrepreneurship merupakan turunan kata entrepreneurship yang terdiri atas dua kata yakni Social yang artinya kemasyarakatan, dan entrepreneurshipyang artinya kewirausahaan. Social entrepreneurship lahir dari adanya seseorang yang memahami adanya persoalan sosial dan menggunakan kemampuan berwirausahanya untuk melakukan perubahan sosial (social change), terutama meliputi bidang kesejahteraan (welfare), pendidikan dan kesehatan (healthcare). ${ }^{38}$ Senada dengan hal ini Haug dalam Dewanto dkk, kewirausahaan sosial adalah usaha untuk memecahkan persoalan di masyarakat dengan prinsip kewirausahaan. ${ }^{39}$ Sehingga pada dasarnya kewirausahaan sosial itu terdapat aktifitas kewirausahaan dengan misi sosial yang dapat memecahkan persoalan di masyarakat.

\footnotetext{
${ }^{31}$ Sugiyono, Metode Penelitian Kuantitatif, Kualitatif dan R \& D (Bandung : CV Alfabeta, 2009). 9-16.

${ }^{32}$ Sandu Siyoto dan M. Ali Sodiq, Dasar Metodologi Penelitian (Yogyakarta : Literasi Media Publishing, 2015). 32.

${ }^{33}$ Amila, Pemberdayaan Ekonomi Masyarakat TunaGrahita melalui Kelompok Swadaya Masyarakat Rumah Harapan Karangpatihan Bangkit (Studi Kasus di Desa Karangpatihan Kecamatan Balong Kabupaten Ponorogo), Tesis Universitas Islam Negeri Maulana Malik Ibrahim Malang, Malang, 2017.

${ }^{34}$ Diah Restu Nur Hasanah, Analisis Model Pemberdayaan Masyarakat pada Warga Tunagrahita di Desa Karangpatihan, Kecamatan Balong, Kabupaten Ponorogo, (Skripsi Jurusan Ekonomi SYariaj Fakultas Ekonomi dan Bisnis, Institut Agama Islam Negeri Ponorogo, 2020 serta Sari Nurfiani, Kewirausahaan Sosial dan Taraf Hidup Masyarakat Tunagrahita (Kajian di "Kampung Idiot" Desa Karangpatihan, Kabupaten Ponorogo, Jawa Timur Institut Pertanian Bogor, 2017.

35 Ibid, 246-253 dan Islamil Nurdin dan Sri Hartati, Metodelogi Penelitian Sosial (Surabaya : Media Sahabat Cendekia, 2019). 208-210.

${ }^{36}$ Sugiyono, Metode Penelitian Kuantitatif, Kualitatif dan R \& D (Bandung : CV Alfabeta, 2009). 241 dan 274.

37Ibid, 272.

38Irma Paramita Sofia, "Konstruksi Model Kewirausahaan Sosial (Social Entrepreneurship) Sebagai Gagasan Inovasi Sosial Bagi Pembangunan Perekonomian", Jurnal Widyakala Universitas Pembangunan Jaya. Vol. 02, No. 02.(2015), 5.

39 Wawan Dhewanto, dkk., Inovasi dan Kewirausahaan Sosial (Jakarta: Alfabeta, 2013). 43.
} 
Adapun Haryanti dkk dalam bukunya mengembangkan konsep Kanva Model Bisnis yakni sebuah metode untuk menggambarkan operasional model bisnis suatu organisasi keseluruhan ketika diterapkan mulai dari menciptakan produk/layanan yang mengandung tawaran nilai kepada konsumen sehingga menghasilkan pendapatan untuk organisasi. ${ }^{40}$ Dari sebelas aspek operasional kewirausahaan sosial ${ }^{41}$ akan membantu mengidentifikasi model suatu kewirausahaan sosial namun utamanya hanya enam unsur yang menjadi pembeda kewirausahaan sosial satu dengan yang lainnya, yaitu : (1) customer segment yakni segmen pengguna layanan/produk berupa konsumen dan penerima manfaat; (2) social value propostitioon adalahtawaran nilai berbentuk misi sosial dalam memecahkan persoalan di masyarakat; (3) adalahsumber daya kunci yang digunakan untuk menghasilkan produk/layanan yang akan ditawarkan kepada segmen pengguna (key resources); (4)berupa arus pendapatan yang diterima dari segmen pengguna akibat dari penerimaan tawaran nilai atau pembelian produk/layanan (revenue stream);(5)adalah skema kepemilikan dan control (ownership and control), dan keenam adalah organizational goal yakniorientasi target pengembangan organisasi. ${ }^{42}$ Secara umum keterhubungan antara dapat dijelaskan pada skema berikut :

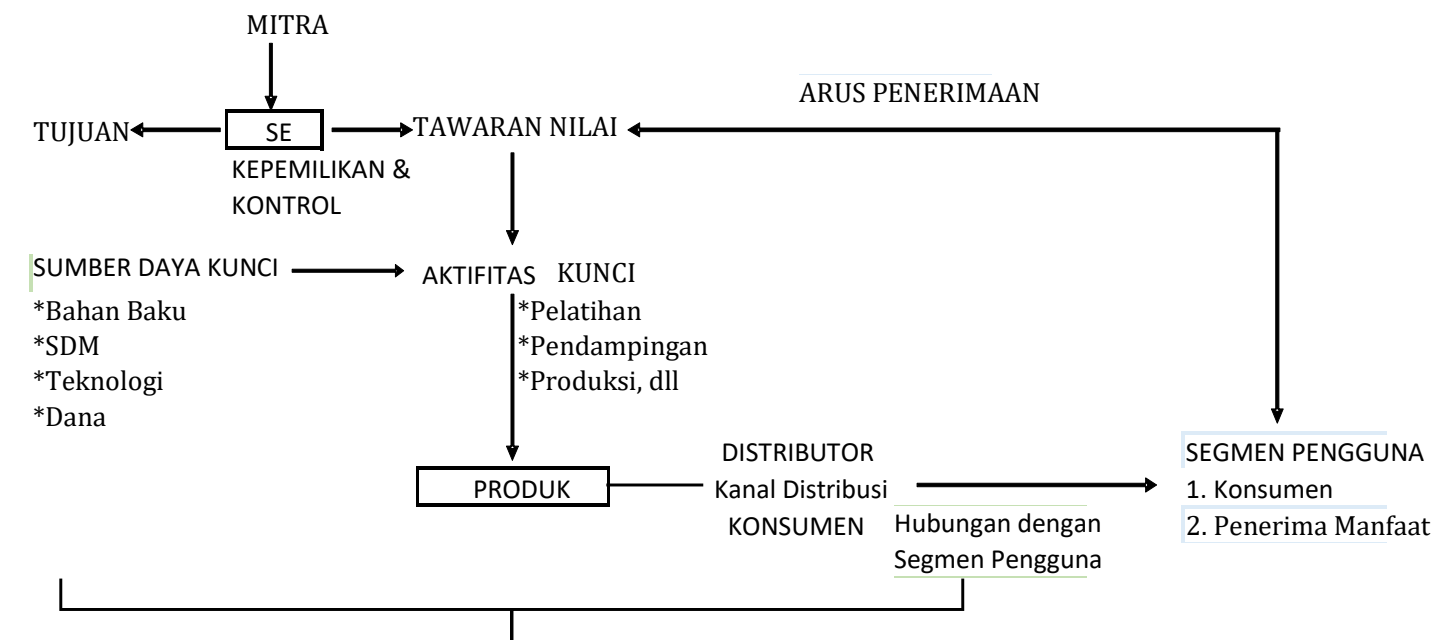

Berdasarkan skem Struktur Biaya t dipahami bahwa organisasi kewirausahaan sosial (SE) memiliki sebuah tujuan untuk mewujudkan misi sosialnya kedepan.Misi sosial ini diwujudkan dalam sebuah produk yang dihasilkan dari aktifitas kunci.Aktifitas kunci tentunya perlu sumber daya untuk dikelola menjadi produk. Setelah produk jadi maka akan ditawarkan kepada segmen pengguna baik secara langsung maupun melalui distributor. Hubungan baik dengan segmen pengguna perlu dilakukan agar mereka mau menerima produk secara berkelanjutan.Dalam kategori Segmen pengguna, konsumen bisa menjadi sekaligus penerima manfaat namun bisa juga mereka merupakan pihak yang berbeda. Ketika segmen pengguna menerima produk/tawaran nilainya maka akan terjadi arus penerimaan kepada organisasi kewirausahaan sosial. Dalam mewujudkan sustainable, maka organisasi juga perlu menjalin kerjasama dengan mitra-mitra yang akan memberikan bantuan sumber daya ataupun dukungan terhadap aktifitas kewirausahaan yang dijalankan. Semua kegiatan kewirausahaan sosial mempunyai asumsi kepemilikan tertentu atas aset-aset yang ada dan pengontrolan terhadap kegiatan usaha agar terus searah dengan misi sosialnya. Dan tentu saja, mengubah sumber daya menjadi produk lalu dipasarkan dan dibeli oleh konsumen itu memerlukan biaya (structure cost).

\footnotetext{
${ }^{40}$ Dewi Meisari Haryanti, dkk.,Berani Jadi Wirausaha Sosial?,(Jakarta: PT. Bank DBS Indonesia, 2015). 178-196.

41 Ibid, 205 - 210

42Ibid, 205 - 210.
} 
Secara teoritis terdapat empat model kewirausahaan sosial di Indonesia berdasarkan kerangka Kanva Model Bisnis ${ }^{43}$ yakni pertama adalah Community Based Social Entreprise dengan asumsi bahwa segmen penggunanya, konsumen dan penerima manfaat merupakan orang yang sama. Tawaran nilainya adalah memberdayakan diri sendiri. Arus penerimaannya dari dana semi komersial. SDMnya adalah relawan.Organisasi dimiliki secara kolektif dan dikontrol secara demokratis.Tujuan organisasi adalah keberlanjutan organisasi saja. Model kedua adalah Not For Profit Social Enterprise Kewirausahaan sosial yang didalam segmen penggunanya, konsumen dan penerima manfaat merupakan orang yang berbeda. Tawaran nilainya adalah memberdayakan orang lain. Arus penerimaannya dari dana sosial. SDMnya adalah relawan dan profesional.Organisasi dimiliki secara kolektif dan dikontrol secara demokratis.Tujuan organisasi adalah keberlanjutan organisasi dan pengembangan program.

Hybrid Social Enterprise adalah model ketiga yang segmen penggunanya, konsumen dan penerima manfaat merupakan orang yang berbeda. Tawaran nilainya adalah memberdayakan orang lain. Arus penerimaannya dari dana sosial, semi komersial dan komersial. SDMnya adalah relawan dan profesional.Organisasi dimiliki secara kolektif dan dikontrol secara demokratis.Tujuan organisasi adalah keberlanjutan organisasi dan pengembangan program. Sedangkan model keempat adalah Profit For Benefit Social Enterprise yang memiliki didalam segmen penggunanya, konsumen dan penerima manfaat merupakan orang yang berbeda. Tawaran nilainya adalah memberdayakan orang lain. Arus penerimaannya dari dana komersial. SDMnya adalah profesional.Organisasi dimiliki secara individu dan dikontrol secara otokrasi.Tujuan organisasi adalah keberlanjutan organisasi, pengembangan program, dan perluasan unit bisnis.

\section{Penerapan Kewirausahaan Sosial RHKB}

Secara umum aplikasi kewirausahaan sosial di RHKB dapat diselaraskan dengan konsep ekonomi Islam mengingat usaha yang dilakukan dalam rangka peningkatan kesejahteraan kaum Tunagrahita yang seluruhnya beragama Islam. Berangkat dari masalah masyarakat tunagrahita disana yang berdampak pada pengangguran dan kemiskinan, Eko Mulyadi bersama masyarakat non tunagrahita berinisiatif membangun Kelompok Swadaya Masyarakat Rumah Harapan Karangpatihan Bangkit dengan mengemban sebuah misi sosial yakni agar masyarakat Tunagrahita bisa sejahtera dan mandiri secara ekonomi melalui serangkaian kegiatan kewirausahaannya. ${ }^{44}$ Adapun secara teori terdapat beberapa nilai universal dalam ekonomi Islam yang menjadi sebagai titik tolak bagi kebijakan-kebijakan ekonomi di kalangan umat muslim yang disarikan dari dan berdasar pada al-tauhid (keimanan), al-'adl (keadilan), al-khilafah (pemerintahan), dan alma'ad (kembali/hasil). 45

Penerapan kewirausahaan social RHKB memiliki aktifitas kunci dalam menghasilkan produk sekaligus memuat misi social yang merupakan bentuk aktualisasi nilai-nilai keimanan bagi para pelakunya.Berdasarkan data dapat diketahui misi sosial RHKB yakni mensejahterakan dan memandirikan kaum tunagrahita untuk bisa menjadi bagian dari makhluk Allah SWT yang sesungguhnya, sejajar dengan manusia normal lainnya.Oleh karenanya RHKB bekerjasama dengan pemerintah desa menjalankan fungsi al-khilafah untuk melakukan aktifitas-aktifitas dengan bentuk pelatihan, pendampingan dan pengadaan variasi bisnis bagi tunagrahita.Dalam pelaksanaannya RHKB menjadikan kaum tunagrahita sebagai SDM bagian produksi yang oleh karenanya perlu diiringi dengan

\footnotetext{
43Ibid, 212 - 235

${ }^{44}$ Sari Nurfiani, Kewirausahaan Sosial,34.

45 IIIy Yanti dan Rafidah, "Ekonomi Islam dalam Sistem Ekonomi Indoensia, (Studi tentang Prinsipprinsip Ekonomi Islam dalam KHES dan Implementasinya terhadap Ekonomi Nasional)", Jurnal Konstikstuaiita, Vol. 25, No. 01. (2009), 17.
} 
kegiatan pelatihan-pelatihan agar terbentuk skill membuat produk. Dalam hal ini kesempatan untuk berproduksi tersebut lebih didasarkan atas prinsip keadilan bahwa pada dasarnya setiap manusia memiliki fitrah yang sama termasuk para tunagrahita asalkan terus berlatih. Sebelum dilatih, RHKB melakukan upaya untuk mendatangkan para tunagrahita agar mau mengikuti kegiatan kewirausahaan, seperti penjemputan, pemberian motivasi material dan non material berupa penjelasan bahwa pendapatan yang diperolehnya dari membuat produk bisa digunakan untuk membeli beras yang merupakan suatu barang mewah bagi tunagrahita. ${ }^{46}$ Setelah dilatih, masyarakat tunagrahita akan terpilih untuk bisa memproduksi jenis usaha yang disediakan RHKB sesuai dengan kemampaun yang dimiliki. Ada yang mampu membuat tasbih namun tidak mampu membuat keset dan sebaliknya. ${ }^{47}$

Produksi di Rumah Harapan Karangpatihan Bangkit dibagi menjadi dua kategori, yaitu produksi ternak dan produksi kerajinan. Produksi ternak dipilih menjadi aktifitas kunci RHKB karena tanah yang dimiliki desa Karangpatihan tidak bagus sehingga tanaman yang ditanam pun akan tidak bagus, sehingga peternakan sebagai solusinya. ${ }^{48}$ Adapun bentuk peternakan yang dikembangkan bagi kaum tunagrahita adalah budidaya ikan lele, kambing, dan ayam kampong.Usaha peternakan diatas dipilih karena termasuk jenis pekerjaan yang mudah dilatihkan bagi tunagrahita.Seperti misalnya budidaya ikan lele menjadi pilihan sebab memiliki mekanisme perawatan yang mudah dan cepat dipanen yakni hanya perlu waktu 3 bulan saja. ${ }^{49}$ Proses pelatihan dan produksi ikan lele dimulai dari perawatan kolam, pemberian pakan hingga pemanenan dijelaskan oleh pelatih dengan praktik langsung dan bahasa isyarat. Contohnya pengisian valume air kolam yang seharusnya, dihitung bukan dengan meteran melainkan dengan isyarat jengkal tangan, kemudian pemberian pakan lele dengan tanda matahari terbit dan tenggelam karena mereka tidak paham konsep jam. ${ }^{50}$ Sistem pelatihan dan pendampingan dengan bahasa tubuh ini nyatanya cukup efektif dalam menjadikan para tunagrahita menjadi produsen komoditas ternak di wilayah Karangpatihan dan sekitarnya hingga sekarang.

Program-program RHKB memiliki nilai sosial guna mensejahterakan dan memandirikan masyarakat tunagrahita dari ketergantungan bantuan konsumtif orang lain. Dalam setiap kali panen ternak lele misalnya, masyarakat tunagrahita diberi pendapatan Rp150.000 - Rp250.000 oleh RHKB.Sedangkan dalam usaha kerajinan misalnya keset mereka mendapatkan penghasilan sebesar Rp7.000 untuk kualitas baik dan Rp7.500 untuk kualitas lebih baik. ${ }^{51}$ Maka pendapatan tunagrahita dari produksi keset sekitar 40\% - 50\% dari harga penjualan keset yaknik Rp15.000. Wujud dari program kewirausahaan social RHKB berupa : (1) Pelatihan, agar masyarakat tunagrahita memiliki skill membuat kerajinan keset, tasbih, batik ciprat, centong-sutil, gantungan kunci serta berternak kambing, lele, ternak ayam kampong; (2) Produksi, agar masyarakat tunagrahita dapat menghasilkan produk baik ternak atau kerajinan yang bisa dijual oleh RHKB dan hasilnya dapat menjadi sumber pendapatan mandiri bagi tunagrahita; (3) Pendampingan, agar masyarakat tunagrahita tidak hanya bisa menghasilkan produk melainkan produk yang berkualitas. Khususnya untuk program pembuatan tasbih, selain

\footnotetext{
${ }^{46}$ Rodhotul Munawaroh dan Refti Handhini Listyani, "Praktik Sosial Pemberdayaan Masyarakat Miskin Idiot melalui Model Kerajinan di Desa Karangpatihan Kecamatan Balong Kabupaten Ponorogo".Jurnal Paradigma Universitas Negeri Surabaya, Vol. 04, No.02. (2016),6-7.

${ }^{47}$ Amalia, Pemberdayaan Ekonomi Masyarakat Tunagrahita melalui Kelompok Swadaya Masyarakat Rumah Harapan Karangpatihan Bangkit (Studi Kasus di Desa Karangpatihan Kecamatan Balong Kabupaten Ponorogo), Tesis Universitas Islam Negeri Maulana Malik Ibrahim Malang, 2017, 87. 48Ibid, 79.

${ }^{49}$ NET.Documentary, "Kisah Eko Mulyadi Pemerhati Tuna Grahita di Ponorogo", dalam www.youtube.com/18-Oktober-2015/diakses20-Januari-2021. 
memiliki nilai sosial juga dimaksudkan agar para tunagrahita dapat tetap menjaga keimanannya lewat kerajinan yang mereka produksi.

Sumber daya kunci yang digunakan RHKB mulai pada proses produksi adalah SDM yang memproduksi adalah tunagrahita ringan dan sedang hingga berat. SDM tunagrahita ringan dan sedang dilibatkan dalam proses ternak lele dan ayam. Budidaya ikan lele ini dapat dipanen dalam kurun waktu 3 bulan, 6 bulan dan 1 tahun sesuai besar kolamnya dan dari hasil panen tersebut masyarakat tunagrahita akan memperoleh penghasilan. ${ }^{52}$ Sedangkan untuk ternak kambing setiap tunagrahita diberikan satu kambing betina dan kambing jantan yang dipelihara secara bergantian dalam satu kelompok tersebut hingga beranak. Kambing pasti perlu rumput untuk makan, disinilah letak pembeda SDM budidaya kambing dengan kegiatan produksi lainnya sebab tidak hanya tungrahita tingkat ringan dan sedang saja yang dilibatkan melainkan juga tunagrahita berat, dengan mengerjakan pekerjaan mencari rumput diladang/sawah yang merupakan pekerjaan terbilang sangat mudah dilakukan. Dalam membuat kerajinan keset memerlukan bahan kain perca kaos dan alat penyatu/pemintal kain perca menjadi keset dan kreatifitas dalam pemilihan susunan warna keset.Semua alat dan bahan tersebut telah disediakan oleh RHKB yang secara produksinya melibatkan para tunagrahita ringan dan sedang yang sudah dilatih selama berbulan-bulan.

Oleh karena kualitas SDM yang minim, pengurus RHKB menerapkan sisem pelatihan dan pendampingan selama proses produksi yang dilakukan para tunagrahita. Pelatihan berfungsi agar masyarakat tunagrahita memiliki skill untuk bisa produksi, sedangkan pendampingan berfungsi agar masyarakat tunagrahita bisa berproduksi secara kualitas.Sehingga pelatihan dan pendampingan berjalan secara simultan yakni pelatihan dan pendampingan usaha ternak dan pembuatan kerajinan.Temuan data yang unik ada pada aspek sudut pandang subjek pelaku wirausaha dimana seluruh SDM produksi adalah tunagrahita sedangkan pelatihan dan pendampingan dilakukan oleh pengurus dan masyarakat karangpatihan yang menjadi relawan dengan prinsip ikhtiyari sebagaimana prinsip ekonomi Islam.Seorang pelatih dan pendamping pasti memerlukan skill untuk melatih. Maka dari itu, pengurus RHKB sebagai pelatih kerajinan dilatih terlebih dahulu oleh Balai Besar Rehabilitasi Sosial Bina Grahita (BBRSBG) Kartini Temanggung sebelum mengajarkan kepada masyarakat tunagrahita, ${ }^{53}$ sedangkan pelatih ternak dari tidak ada pelatihan khusus karena sudah memiliki skill tersebut sebelumnya.

Untuk menjalankan program kewirausahaan social, maka RHKB memiliki sumber dana dan mitra usaha. Adapun beberapa sumber dana yang bisa digunakan ke seluruh kegiatan pelatihan, produksi, pendampingan hingga menghasilakan hasil ternak maupun kerajinan yakni dari dana CSR, BI Kediri dan juga alokasi dari dana zakat masyarakat. Dalam hal ini dengan melakukan manajemen dana zakat yang baik ${ }^{54}$, dapat mengatasi problematika minimnya sumber dana dalam usaha kewirausaaan sosial yang dilakukan. Selain CSR, dalam pengembangan kegiatan usaha warga tunagrahita mendapat dana dari donatur yang berkunjung ke Karangpatihan serta memanfaatkan hasil dari pengelolaan dana zakat oleh Unit Penyalur Zakat. Pengurus UPZ Karangpatihan menerima dan menyalurkan dana zakat yang salah satunya untuk pemberdayaan ekonomi kurang

\footnotetext{
52 Amalia, Pemberdayaan Ekonomi ,79-81.

53 Bambang Triono, "Kebijakan Pemberdayaan Masyarakat Difabel Idiot di Desa Karangpatihan Kecamatan Balong Kabupaten Ponorogo", Jurnal Ilmu Administrasi Publik. Vol. 05, No.01 (2018), 100.

${ }^{54}$ Wulandari, Sri Dewi. Analisis manajemen dakwah pada program Bina Mandiri Wirausaha Lembaga Amil Zakat Infaq dan Shodaqoh Muhammadiyah Surabaya. Diss. UIN Sunan Ampel Surabaya, 2017, 7.
} 
mampu termasuk dalam hal ini para tunagrahita. ${ }^{55}$ Selain itu juga Desa juga menyuntikkan dana untuk pemberdayaan tungrahita sekitar 10\%56 hingga hampIr 30\% dari dana desa. ${ }^{57}$ Dari hasil penjualan kerajinan tangan keset, tasbih dan juga batik ciprat $40 \%-50 \%$ akan diberikan kepada pembuat dan 50\% - 60\% dimasukkan kas untuk digunakan putaran modal kegiatan usaha dan ekspansi bisnis. Pihak-pihak diluar RKHB tersebut, telah bantuan materiil maupun non dapat dikategorikan sebagai mitra dalam pengadaan sumber daya modal dan SDM penopang aktifitas kunci dari RHKB. Produk-produk tunagrahita dalam program kewirausahaan social RHKB yang dihasilkan tersebut nantinya akan dijual dengan memanfaatkan kanal distribusi dan hubungan dengan konsumen.

Sejak awal berdirinya RHKB pada 2013, RHKB memang ingin lebih fokus untuk menjalankan misi sosialnya yaitu menyelesikan persoalan ketidaksejahteraan dan ketidakmandirian dari masyarakat tunagrahita di desa Karangpatihan.Berdasarkan fakta di lapangan, kajian ini menemukan bahwa segmen pengguna RHKB menggunakan model konsumen merupakan pihak yang berbeda dengan penerima manfaat.Pihak yang berperan sebagai konsumen bagi RHKB terbagi menjadi dua yakni pertama konsumen bisnis yang yang membeli produk berupa hasil ternak dan atau hasil kerajinan, serta kedua adalah konsumen sosial (donatur) yakni pihak yang memberikan dananya untuk program pemberdayaan ekonomi RHKB setelah mereka menerima value dari produk sosialnya. Dalam hal ini yang termasuk dalam konsumen bisnis adalah pengunjung desa Karangpatihan ${ }^{58}$, Pengunjung expo/pameran didalam/diluar kota Ponorogo yang diikuti oleh RHKB ${ }^{59}$, Jaringan pengurus RHKB ${ }^{60}$, Pengguna media sosial ${ }^{61}$, dan masyarakat Karangpatihan ${ }^{62}$ yang membeli produk-produk ternak dan kerajinan di RHKB sebagai cindera mata. Sedangkan donaturnya adalah Bank Indonesia Kediri63, perusahaan swasta, kepala desa Karangpatihan, perusahaan swasta dan masyarakat setempat yang memberikan bantuan dana/material untuk kegiatan RHKB.Adapun sasaran penerima manfaat dari kegiatan kewirausahaan sosial RHKB adalah masyarakat tunagrahita ${ }^{64}$ yakni memiliki skill untuk bekerja di RHKB sebagai SDM produksi, menjadi pekerja tetap dengan pendapatan rutin selama masih berproduksi, terdapat Inovasi dalam membuat produk yang berkualitas sehingga berpeluang berpenghasilan lebih banyak khususnya dalam kerajinan keset.

RHKB memang telah menetapkan harga produknya dan konsumen akan membayar sesuai harga yang telah ditetapkan. Walaupun, RHKB dalam menetapkan harga produknya lebih dimahalkan dibanding harga pada umumnya, tetapi konsumen RHKB tetap mau membelinya.Kemudian, pernah ada fenomena dimana produk kerajinan tasbih diterima konsumen dengan jumlah manik-manik kurang dari yang seharusnya, namun oleh konsumen tersebut produk tasbih itu tetap dibeli dengan alasan untuk kenang-kenangan

\footnotetext{
55Pemerintah Desa Karangpatihan, Bantuan BAZNAZ di Desa Karangpatihan”, Website Desa Karangpatihan,“30 januari 2021.

56Ibid, 103

57The Nation Metro TV, “Bukan Desa Idiot (2/3)”, dalam www.youtube.com/9-Oktober-2019 21januari-2021.

58 Sari Nurfiani, Kewirausahaan Sosial, 54.

59 Ibid

60 Amalia, Pemberdayaan Ekonomi ,123.

61Ibid, 123.

62 Bambang Triono, "Kebijakan Pemberdayaan Masyarakat Difabel Idiot di Desa Karangpatihan Kecamatan Balong Kabupaten Ponorogo", Jurnal Ilmu Administrasi Publik. Vol. 5, No. 01.(2018), 105.

63 Amalia, Pemberdayaan Ekonomi ,116.

64The Nation Metro TV, "Bukan Desa Idiot (2/3)", dalam www.youtube.com/9-Oktober-2019 21januari-2021.
} 
buatan tunagrahita.Hal itu berarti ada dari konsumen RHKB yang tidak hanya sekedar membeli produk RHKB melainkan ada keinginan agar nilai sosial yang terkandung dalam produk dapat terus berjalan.Temuan ini barangkali dapat menjadi penguat teori yang dikemukakan oleh Dewi Meisari Haryanti, dkk tentang Social ValuePreporsition pada kewirausahaan sosial. ${ }^{65}$ Sedangkan cara yang dilakukan dalam cara menjalin hubungan khususnya dengan konsumen bisnis agar senantiasa "loyal" terhadap produk RHKB adalah dengan menjaga kualitas dari produk meskipun pembuatanya dari tangan tunagrahita. Untuk itu selain menonjolkan misi social mensejahterakan para tunagrahita secara beradab, RHKB juga membuat sistem jumlah minimal penyetoran produk, dan pembayaran tunagrahita disesuaikan dengan kualiatas hasil garapan. ${ }^{66}$ Disatu sisi untuk konsumen warga desa \& pengunjung, Eko Mulyadi sekaligus Pelindung RHKB membuat peraturan bahwa mereka bagi mereka yang melakukan kajian, KKN, atau kegiatan lainnya di Karangpatihan diharuskan minimal membeli satu produk kerajinan RHKB67. Hubungan kedekatan berupa sikap terbuka dan familiar juga dijadikan cara dalam menjalin hubungan dengan penerima manfaat dan para pengurus RHKB.

Dalam hal keuangan terdapat struktur biaya berupa rincian biaya yang harus dikeluarkan RHKB dari pengadaan sumber daya, proses pengolahan sumber daya hingga penjualan produk.Secara garis besar, keuangan RHKB, sebagaian untuk pendapatan mandiri tunagrahita sebagaian lainnya untuk bisaya operasional RHKB dan ekpansi bisnis. ${ }^{68}$ Sedangkan dari arus penerimaan kajian ini menemukan data bahwasannya hanya terdapat dua bentuk sumber dana RHKB yakni dana sosial dari donatur dan dana komersial dari pendapatan atas penjualan produk bisnis RHKB kepada konsumen. Adapun sumber dana yang menjadi key resources RHKB sekaligus menjadi revenue stream RHKBdan disisi lain pula, mitra yang memberikan sumber daya kunci berupa dana ternyata juga sekaligus menjadi donatur.

\section{Model Kewirausahaan Sosial Komunitas Muslim RHKB}

Model Kewirausahaan Sosial yang sesuai dengan asumsi dasar masyarakat menjadi sangat penting untuk pengembangan masyarakat Islam apalagi dalam konteks keterbelakangan mental seperti kaum Tunagrahita di desa Karangpatihan. Adapun model kewirausahaan social RHKB akan dibahas kedalam enam indicator sebagai berikut :

Pertama, ditinjau dari aspek kepemilikan dan control RHKB dapat diketahui bahwa organisasi ini dibangun secara swadaya oleh masyarakat setempat agar bisa lebih fokus pada program-program untuk masyarakat tunagrahita tanpa perlu membawa masyarakat Tunagrahita keluar desa untuk memperoleh pelatihan-pelatihan keterampilan kewirausahaan sehingga lebih mudah dalam melakukan pengontrolan. Bentuk kontribusi dan swadaya masyarakat desa Karangpatihan dalam pembangunan Rumah Harapan Karangpatihan Bangkit ini adalah dengan pemberian zakat untuk dikelola oleh UPZ sebagai modal awal, selain itu aja juga yang mewakafkan tanahnya, menyumbang semen, batu bata, batu gamping, dll untuk pembangunan gedung RHKB serta ada juga yang memberikan alat-alat produksi untuk kerajinan keset.69 Dari terbentuknya RHKB maka terbentuk pula struktur kepengurusan RHKB hasil dari musyawarah masyarakat Karangpatihan dengan sebagian perangkat desa.

Secara pengontrolan, sejak awal RHKB berdiri pada tahun 2013, keputusankeputusan penting seperti pembentukan pengurus RHKB sebagai perwakilan dari masyarakat Karangpatihan, diputuskan secara musyawarah oleh masyarakat

\footnotetext{
65 Dewi Meisari Hardiyanti, dkk.,Berani Jadi Wirausaha Sosial?,(Jakarta: PT. Bank DBS Indonesia, 2015), 206.

${ }^{66}$ Sari Nurfiani, Kewirausahaan Sosial,41.

67Ibid, 54 .

68Ibid, 39.

69Ibid, 77.
} 
sendiri. ${ }^{70}$ Sehingga dapat dikatakan bahwa RHKB bukan milik satu individu tertentu melainkan milik bersama maka aset-aset RHKB milik organisasi yang bersifat kolektif.Dalam pelaksanaannya, pengurus juga mengadakan rapat rutin untuk membahas permasalahan-permasalahan RHKB dalam menjalankan pemberdayaan kepada masyarakat tunagrahita.Hai ini ditunjukkan dengan adanya data bahwa dalam RHKB mempercayai setiap warga merupakan inovator desa. ${ }^{71}$ Sehingga, pengontrolan dalam organisasi ini ini tidak yang bersifat otokratis yang saklek arahan dari satu individu melainkan hasil berbagai pikiran masyarakat.

Dengan melihat ownership and control RHKB, model kewirausahaannya lebih mengarah kepada not for profit social entreprise, dan hybrid social entreprise yang mengacu pada asumsi kepemilikan dan kontrol organisasi adalah kolektif-demokratis. Hal yang perlu digarisbawahi adanya kekhasan tersendiri adalah dalam aspek kepemilikan dan kontrol bersama pada RHKB yakni dibangun atas dasar pemahaman bersama masyarakat karangpatihan bahwa kaum tunagrahita dapat menjadi "normal" dengan memiliki hak dan tanggung jawab yang sama sebagaimana manusia ciptaan Allah SWT lainnya. Adanya bentuk teladan sikap kepedulian social dari sosok kepala desa Eko Mulyadi terhadap para penyandang tunagrahita tampaknya dapat menggerakkan semangat kolektifitas warga untuk membantu sesama muslim yang mengalami penderitaan hidup.

Aspek kedua selain faktor kepemilihan dan kontrol aspek yang perlu diperhatikan yakni Organization Goals.Berdasarkan temuan data tujuan kewirausahaan sosial RHKB adalah sustainable, development and growth.Dalam rangka keberlanjutan organisasi, RHKB melakukan pengkaderan, menjalin hubungan baik dengan segmen pengguna baik kepada konsumen, donatur maupun penerima manfaat dan adanya pengelolaan keuangan dari hasil penjualan.Pengkaderan RHKB dilakukan secara informal, tidak ada pendaftaran dan seleksi.Pergantian jabatan didasarkan pada kemampuan dan pengalaman yang dimiliki.Misalkan, pergantian ketua baru, maka ketua baru itu pasti orang dibawah ketua lama yang secara catatan telah mengikuti kegiatan kepemudaan desa yang kemudian dibina untuk mengurusi di RHKB. ${ }^{72}$ Hubungan baik dengan segmen pengguna juga merupakan upaya agar RHKB sustainable. Sebab pertama, jika konsumen atau donatur hanya sekali saja memberikan dananya ke RHKB, tandanya arus penerimaan hanya terjadi satu kali juga, dampaknya pengadaan sumber daya untuk produksi selanjutnya terhambat maka akan terjadi kemacetan bahkan kemandekan dalam operasionalisasi selanjutnya. Sebab kedua, jika RHKB tidak menjalin hubungan baik kepada penerima manfaat maka tunagrahita tidak mau lagi dilatih dan diberdayakan dengan bekerja di RHKB padahal tunagrahita adalah SDM produksi yang tidak bisa digantikan.Hal ini disebabkan karena misi social RHKB yakni pemberdayaan tunagrahita itu sendiri. Secara tujuan perluasan unit bisnis atau konsumen, ditunjukkan oleh RHKB dengan adanya dana untuk ekspansi bisnis dan adanya pengiriman produk kerajinannya ke berbagai expo/ pameran, tidak hanya di dalam Ponorogo melainkan juga di luar Ponorogo, penjualan batik ciprat juga telah merambah di segmen nasional dengan menerima pesanan dari beberapa kota di Indonesia. ${ }^{33}$ Bahkan, penjualan produk RHKB melalui media online yang tandanya produk RHKB bisa diakses siapapun di dunia, semakin menguatkan bahwa RHKB berupaya memperluas konsumennya. Dengan melihat dari segi tujuanRHKB yakni sustainable development and growth, model kewirausahaan sosial yang sesuai lebih mengarah kepada

\footnotetext{
70Ibid, 73.

71Sari Nurfiani, Kewirausahaan Sosial,53.

72 Sari Nurfiani, Kewirausahaan Sosial, 39.

${ }^{73}$ Diah Restu Nur Hasanah, Analisis Model Pemberdayaan Masyarakat pada warga Tunagrahita di Desa Karangpatihan, Kecamatan Balong, Kabupaten Ponorogo, Skripsi Institut Agama Islam Negeri Ponorogo, 2020), 55.
} 
model profit for benefit social entreprice. Sebab community based social entreprise hanya bertujuan berkelanjutan, not for profit social entreprise dan hybrid social entreprise bertujuan berkelanjutan dan pengembangan usaha.

Aspek tawaran nilai merupakan hal ketiga yang dalam konteks RHKB merujuk pada ciri khas people empowernment. RHKB dibentuk oleh masyarakat desa Karangpatihan non tunagrahita untuk memberdayakan masyarakat tunagrahita di desanya sehingga kewirausahaan sosial yang dilakukan RHKB untuk memberdayakan orang lain bukan diri sendiri. Maka dari itu, misi sosial RHKB adalah mensejahterakan dan memandirikan tunagrahita desa Karangpatihan melalui kegiatan kewirausahaan sosial yang diadakan di RHKB.Misi sosial tersebut diturunkan menjadi manfaat-manfaat yang dapat dirasakan oleh tunagrahita yakni bisa memperoleh skill dan pekerjaan tambahan baik dari rumah tangganya sendiri maupun bekerjasama dengan warga masyarakat lainnya. Peningkatan skill dalam pekerjaan yang dijalani akan linier dengan peningkatan pendapatan dan kualitas pemenuhan kebutuhan hidup yang layak bagi keluarga dan keturunannya. Selain itu nilai ekonomi, juga terdapat nilai social yang dirasakan oleh tunagrahita yakni meningkatnya status social dengan dipatahkannya stigma masyarakat umum dengan melihat kemampuan tunagrahita bekerja di RHKB, menghasilkan pendapatan mandiri untuk memenuhi kebutuhannya sendiri.Dengan melihat dari segi social value preporsition RHKB, model kewirausahaan sosial RHKB lebih mengarah pada not for profit social entreprise, hybrid social entreprise, dan profit for benefit social entreprise.Namun terdapat kekhasan dari value prepotitionnya yaitu ditemukan adanya kenaikan kelas sosial selain manfaatkan ekonomi yang dirasakan tunagrahita.

Oleh karena social value proporsition RHKB adalah people empowermet, bukan memberdayakan diri sendiri maka secara otomatis segmen pengguna RHKB bermodel konsumen merupakan individu yang berbeda dari penerima manfaat.Dalam hal konsumen ternyata tidak hanya konsumen bisnis melainkan juga konsumen sosial/ donatur. Dengan melihat dari segi customer segment RHKB, model kewirausahaan sosial RHKB juga jelas bukan community based social entreprise yang mana customer segment-nya adalah konsumen merupakan individu yang sama dengan penerima manfaat. Namun, sesuai dengan not for profit social entreprise, hybrid social entreprise, danprofit for benefit social entreprise dimana customer segment-nya adalah konsumen merupakan individu berbeda dengan penerima manfaat.

Sedangkan pada aspek kelima yakni arus penerimaan ini sangat terkait dengan segmen pengguna.Dari penjelasan segmen pengguna RHKB di atas, konsumen adalah individu yang berbeda dengan penerima manfaat. Dan konsumen RHKB dibagi lagi menjadi konsumen bisnis dan donatur sehingga terbentuk 2 arus penerimaan di RHK yaitu dana sosial dari donatur dan dana komersial dari hasil penjualan produk bisnis konsumen. Dengan melihat dari segi revenue stream RHKB, model kewirausahaan sosial RHKB yang mendekati adalah model hybrid social entreprise. Namun RHKB memiliki karakteristik yang berbeda, pada hybrid social entreprise menggunakan dana sosial, semi komersial dan komersial sedangkan mereka hanya ada dana sosial dan komersial.

Dalam aspek keenam yakni model SDM RHKB menggunakan tenaga profesional dan relawan. Dan uniknya, tenaga yang dibayar secara profesional adalah tunagrahita itu sendiri.Walaupun tunagrahita, mereka tetap mampu menghasilkan produk sesuai kualitas dan digaji berdasarkan kualitas produk yang dihasilkan dengan pelatihan dan pembimbingan yang konsisten.Melatih dan mendampingi masyarakat tunagrahita agar bisa memiliki skill untuk produksi bukan soal mudah, pelatih dan pendamping harus memiliki kesabaran dan memerlukan waktu yang lama, seperti melatih berternak lele perlu waktu berminggu-minggu ${ }^{74}$ dan bahkan melatih kerajinan keset bisa memakan

74 NET.Documentary, "Kisah Eko Mulyadi Pemerhati Tuna Grahita di Ponorogo", dalam www.youtube.com/18-Oktober-2015/diakses20-Januari-2021. 
waktu hingga 3 tahun lamanya. ${ }^{75}$ Dalam hal ini pelatih dan pendamping dari pengurus ataupun relawan tidak ada yang dibayar dan merekapun tidak mengharapkan gaji, hanya memiliki niat menolong tunagrahita.Dengan melihat dari segi human resources RHKB, model kewirausahaan sosial RHKB lebih mengarah pada model not for profit social entreprise ataupun hybrid social entreprise yang menggunakan SDM percampuran relawan dan profesional.

Dari analisis 6 aspek diatas, model kewirausahaan sosial RHKB lebih cenderung kepada model hybrid social entreprise. Meskipun berkecenderungan sama namun sebenarnya RHKB memiliki karakteristik tersendiri. Letak persamaannya pada social value preporsition-nya people empowerment, customer segmen-nya konsumen merupakan individu yang berbeda dari penerima manfaat, human resources-nya perpaduan professional dan relawan, dan owner and control-nya kolektif dan demokratis.Sedangkan, letak perbedaannya pada aspek arus penerimaan (revenue stream) dan tujuan organisasi (organization goals). Pada model hybrid, arus penerimaannya menggunakan tiga sumber dana yaitu dana sosial, semikomersial dan komersial, namun pada RHKB hanya menggunakan dua sumber dana yaitu dana sosial dari para donatur dan dana komersial dari hasil penjualan produk bisnis. Hal ini bisa terjadi karena model kewirausahaan sosial memang dibuat menyesuaikan kondisi SE. Perbedaan berikutnya adala dari tujuan organisasi RHKB yaitu sustainable development and growth seperti tujuan dari model profit for benefit social entreprise. Pada model hybrid social entreprise, tujuannya hanya sustainable development.Di RHKB ada tujuan growth ditandai dengan adanya upaya perluasan pasar/konsumen ke berbagai wilayah di Indonesia melalui /expo didalam/diluar Ponorogo dan di dunia media sosial.

\section{Penutup}

Kewirausahaan sosial merupakan kewirausahaan yang tidak hanya mengejar keuntungan melainkan juga untuk menyelesaikan masalah sosial yang ada di masyarakat.Kelompok Swadaya Masyarakat Rumah Harapan Karangpatihan Bangkit merupakan organisasi kewirausahaan sosial yang berhasil menyelesaikan persoalan yang dihadapi oleh masyarakat tunagrahita desa Karangpatihan terkait ketidaksejahteraan dan ketidakmandirian dalam memenuhi kebutuhan hidupnya sendiri.RHKB memberikan pelatihan dan pendampingan kepada tunagrahita sehingga mereka memiliki skill untuk produksi produk di RHKB secara berkualitas. Kemudian, dari hasil penjualan produk yang dihasilkan akan menjadi pendapatan mandiri harian, bulanan, triwuan dan tahunan bagi tunagrahita yang nantinya bisa digunakan oleh mereka dalam memenuhi kebutuhan hidupnya sendiri. Keberhasilan RHKB tidak terlepas dari model kewirausahaan yang dipilihnya yaitu cenderung sama seperti hybrid social entreprise namun tetap memiliki karakteristiknya sendiri terutama pada indikator revenue stream dan goal organization, sebagai berikut:

Pertama tawaran nilai (social value proporsition) RHKB adalah peopleempowerment.Masyarakat Karangpatihan non tunagrahita secara swadaya memberdayakan masyarakat tunagrahita di desanya melalui kegiatan kewirausahaan sosial yang diadakan di RHKB, meliputi kegiatan pelatihan dan pendampingan sehingga tunagrahita memiliki skill dan memproduksi kerajinan. Selain adanya manfaat langsung yang dirasakan tunagrahita berupa adanya peningkatan skill, bisa bekerja, peningkatan pendapatan dan pemenuhan kebutuhan, ada juga manfaat tidak langsung berupa meningkatnya status sosial tunagrahita dimata masyarakat umum dimana dulunya masyarakat tunagrahita dianggap tidak bisa melakukan apa-apa namun berkat adanya RHKB, stigma dimasyarakat itu terpatahkan.

75 The Nation, Bukan Desa Idiot (2/3), Video YouTube, 06:50, dikirim oleh The Nation Metro TV, 9 Oktober 2019. 
Kedua segmen pengguna (customer segment) RHKB otomatis jika melihat dari tawaran nilai RHKB adalah model konsumen merupakan individu yang berbeda dari penerima manfaat. Uniknya pada sisi konsumen RHKB tidak hanya ada konsumen bisnis melainkan juga konsumen sosial (donatur).Konsumen bisnis adalah konsumen yang membeli produk-produk bisnis RHKB yaitu lele, kambing, ayam kampung, telur ayam kampong, kerajinan tasbih, keset, dan batik cipratdan.Donatur adalah individu atau kelompok yang berkontribusi pada produk sosial RHKB yaitu kegiatan kewirausahaan sosial RHKB.Penerima manfaat RHKB adalah tunagrahita desa Karangpatihan kategori ringan, sedang bahkan berat.

Ketiga arus penerimaan (revenue stream) RHKB hanya dari dua sumber dana, yaitu dana sosial dari donatur yang berkontribusi dalam produk sosial RHKB dan dana komersial dari penjualan produk bisnis RHKB kepada konsumen. Hal ini yang membedakan dari model hybrid social entreprise dimana menggunakan 3 sumber dana yaitu dana sosial, semi komersial dan komersial, di RHKB tidak ada dana semikomersial. Dan uniknya juga di RHKB ini, donatur merupakan subjek yang sama dengan mitra yang memberikan bantuan sumber daya berupa dana.

Keempat SDM RHKB adalah percampuran profesional dan relawan.Uniknya yang menjadi profesional adalah SDM tunagrahita.Walaupun banyak keterbatasan yang dimiliki oleh tunagrahita namun mereka tetap mampu menghasilkan produk kualitas dan dibayar sesuai dengan kualitas yang digarap. Dan para pelatih dan pendamping yang tidak lain adalah pengurus RHKB dan masyarakat Karangpatihan bekerja secara sukarelawan tanpa mengharapkan bayaran.

Kelima kepemilikan dan kontrol RHKB adalah kolektif-demokratis.Karena RHKB dibangun secara swadaya oleh masyarakat Karangpatihan sehingga RHKB dimiliki secara kolektif dan dikontrol secara bersama-sama.

Keenam tujuan dari RHKB yaitu sustainable development and growth.Keberlanjutan RHKB dengan melakukan pengkaderan, menjalin hubungan baik kepada konsumen ataupun donatur agar terjadi arus penerimaan secara berkelanjutan dan kepada penerima manfaat sebagai SDM produksi agar mau memproduksi terus menerus dan RHKB juga melakukan pengelolaan keuangan, sebagian untuk pendapatan tunagrahita dan sebagian lagi untuk memperluas lini bisnis dan biaya operasional selanjutnya. Pengembangan RHKB diwujudkan dengan perbaikan kualitas kegiatan dan menyiapkan kegiatan baru yang prospek di masa mendatang dengan menggandeng berbagai mitra. Indiator tujuan ini juga menjadi sisi unik dari RHKB karena dalam model hybrid social entreprise hanya bertujuan sustainable development namun di RHKB sutainable development and growth.

\section{Daftar Pustaka}

Aji, Isbandi Rukminto. Intervensi Komunitas dan Pengembangan Masyarakat sebagai Upaya Pemberdayaan Masyarakat Edisi Revisi. (Jakarta: PT RajaGrafindo Persada, 2012)

Amalia.Pemberdayaan Ekonomi Masyarakat Tunagrahita melalui Kelompok Swadaya Masyarakat Rumah Harapan Karangpatihan Bangkit (Studi Kasus di Desa Karangpatihan Kecamatan Balong Kabupaten Ponorogo). Program Pascasarjana, Universitas Islam Negeri Maulana Malik Ibrahim Malang, 2017.

Aziz, Muhammad Wildan. Kewirausahaan Sosial sebagai Alternatif Pemberdayaan Masyarakat."Jurnal Institut Pertanian Bogor.Vol. 06, No. 05. (2018).

Departemen Agama RI. Al-Qur'an Tajwid dan Terjemah. (Jakarta: Dharma Art, 2015)

Dewi, Dian Suluh Kusuma. Model Pemberdayaan Masyarakat Tunagrahita di Kampung Idiot Kabupaten Ponorogo. Jurnal Ilmu Pemerintahan. Vol. 06, No.01. (2016) 
Cabilah: Journal of Social Community

Terakreditasi Nasional SKNo.14/E/KPT/2019
Print-ISSN: 2502-96490nline-ISSN: 2503-3603

Vol. 6 No.1 Juni 2021

Dhewanto, wawan, Hendrati Dwi Mulyaningsih, Anggraeni Permatasari, Grisna Anggadwita, Indriany Ameka. Inovasi dan Kewirausahaan Sosial. (Jakarta : Alfabeta. 2013)

Firdaus, Nur. Pengentasan Kemiskinan melalui Pendekatan Kewirausahaan Sosial.Jurnal Ekonomi dan Pembangunan Lembaga Ilmu Pengetahuan Indonesia.Vol. 22, No. 01. (2014),

Haryanti, Dewi Meisari, Sri Rahayu Hijrah Hati, Astari Wirastuti, dan Kumala Susanto. Berani Jadi Wirausaha Sosial?. (Depok : PT Bank DBS Indonesia, 2015)

Hasanah, Diah Restu Nur. Analisis Model Pemberdayaan Masyarakat pada warga Tunagrahita di Desa Karangpatihan, Kecamatan Balong, Kabupaten Ponorogo.Skripsi Jurusan Ekonomi Syariah Institut Agama Islam Negeri Ponorogo, 2020.

Kaswan dan Ade Sadikin Akhyadi.Social Entrepreneurship: mengubah masalah sosial menjadi peluang usaha. (Bandung: Alfabeta, 2015)

Kementrian Sosial Republik Indonesia.Kementrian Sosial dalam Angka Pembangunan Kesejahteraan Sosial. (Jakarta : Badan Pendidikan dan Penelitian Kesejahteraan Sosial Pusat Data dan Informasi Kesejahteraan Sosial, 2012)

Lisinus, Rafael dan Pastiria Sembiring.Pembinaan Anak Berkebutuhan Khusus (Sebuah Perspektif Bimbingan dan Konseling). (Jakarta : Yayasan Kita Menulis, 2020)

Machendrawaty, Nanih. Pengembangan Masyarakat Islam dari Ideologi, Strategi, sampai Tradisi. (Bandung: PT Remaja Rosdakarya, 2001)

Mawasti, Wahanani, and Tri Djoyo Budiono.Memberdayaan Masyarakat Islam Melalui Bank Sampah:Strategi Komunikasi Stakeholder Bank Sampak Songolikoer." InteleksiaJurnal Pengembangan Ilmu Dakwah.Vol. 01, No.02.(2020).

Munawaroh, Rodhotul dan Refti Handhini Listyani.Praktik Sosial Pemberdayaan Masyarakat Miskin Idiot melalui Model Kerajinan di Desa Karangpatihan Kecamatan Balong Kabupaten Ponorogo" Jurnal Paradigma Universitas Negeri Surabaya.Vol. 04, No.02. (2016).

Nugroho, Agus. Peningkatan Kewirausahaan Masyarakat Tunagrahita Melalui Dana Desa di Desa Karangpatihan Ponorogo. Jurusan Perbankan Syariah, Universitas Islam Negeri Maulana Malik Ibrahim Malang, 2019.

Nurdin, Islamil dan Sri Hartati.Metodelogi Penelitian Sosial. (Surabaya: Media Sahabat Cendekia, 2019)

Nurfiani, Sari. Kewirausahaan Sosial dan Taraf Hidup Masyarakat Tunagrahita (Kajian di 'Kampung Idiot' Desa Karangpatihan, Kabupaten Ponorogo, Jawa Timur, Departemen Sains Komunikasi dan Pengembangan Masyarakat, Institut Pertanian Bogor, 2017.

Palesangi, Muliadi. Pemuda Indonesia dan Kewirausahaan Sosial. Jurnal Universitas Katalik Parahyangan. Vol. 01, No. 02. (2012).

Ramadhianto, Mahendra. Upaya Peningkatan Kesejahteraan Sosial bagi Penyandang Cacat (Studi Implementasi Pasal 7 Undang-Undang Republik Indonesia Nomor 11 Tahun 2009 tentang Kesejahteraan Sosial di Desa Karangpatihan Kecamatan Balong Kabupaten Ponorogo). Jurusan Hukum Administrasi Negara, Universitas Brawijaya Malang, 2013.

Sepprian, Okky.Pemberdayaan Masyarakat melalui Rumah Harapan dalam Memberikan Life Skill Kerajinan Tangan Warga Tunagrahita Desa Karangpatihan Kecamatan Balong Kabupaten Ponorogo.Jurnal Universitas Negeri Surabaya.Vol. 07, No.02.(2018).

Siyoto, Sandu dan M. Ali Sodiq.Dasar Metodologi Penelitian. (Yogyakarta : Literasi Media Publishing, 2015) 
Sofia, Irma Paramita. Konstruksi Model Kewirausahaan Sosial (Social Entrepreneurship) Sebagai Gagasan Inovasi Sosial Bagi Pembangunan Perekonomian.Jurnal Widyakala Universitas Pembangunan Jaya. Vol. 02, No. 02. (2015)

Sugiyono.Metode Penelitian Kuantitatif, Kualitatif dan R \& D. (Bandung : CV Alfabeta, 2009)

Triono, Bambang. Kebijakan Pemberdayaan Masyarakat Difabel Idiot di Desa Karangpatihan Kecamatan Balong Kabupaten Ponorogo. Jurnal Ilmu Administrasi Publik. Vol. 05, No.01 (2018).

Utomo, Hardi. Menumbuhkan Kewirausahaan Sosial. Jurnal Ilmiah Among Makarti. Vol.07, No.14.(2014).

Wulandari, Sri Dewi. Analisis manajemen dakwah pada program Bina Mandiri Wirausaha Lembaga Amil Zakat Infaq dan Shodaqoh Muhammadiyah Surabaya.Diss. UIN Sunan Ampel Surabaya, 2017.

Citradi, Tirta. IPM RI Naik, Tapi Masih Kalah sama Tetangga, CNBCIndonesia. 17 Februari, 2020.

Firmanto, Danang. CSR Bank Indonesia Difokuskan pada 3 Program Ini, Tempo. 21 April, 2016.

Haimi, Denisa Libela. Hubungan Down Syndrome dengan Tunagrahita, Alodokter.31 Januari 2019.

NET, Documentary. Kisah Eko Mulyadi Pemerhati Tuna Grahita di Ponorogo. Video YouTube. 00:00 - 23:18, 18 Oktober 2015.

Susanto, Aries. Daerah Tertinggal Ponorogo : Inilah Cerita di Balik Desa Keterbelakangan Mental Terbanyak di Indonesia, Solo Pos. 7 Januari 2015.

Metro TV, The Nation. Bukan Desa Idiot (1/3). Video Youtube, 09 Oktober 2019. 